\title{
A land of milk and honey? Making sense of Aotearoa New Zealand
}

\author{
Avril Bell, Vivienne Elizabeth, Tracey Mclntosh and \\ Matt Wynyard (Eds.), 2017 \\ Auckland University Press, Auckland, New Zealand \\ ISBN 9781869408626, pp. 336, paperback, NZD59.99
}

$\mathrm{T}$ This is an edited collection of 21 chapters written by sociologists for Aotearoa New Zealand students. The target readers are sociology students; however, it is a useful text for a range of disciplines, particularly social work. It would be a handy text for first-year degree students as the chapters are short and provide an introduction to the chapter topic. The book was published in 2017 and is therefore current, however some content will become dated as changes in legislation and funding priorities made by the Labour-led coalition take effect. One of the strengths of the book is the broad range of topics introduced, providing an overview of Aotearoa New Zealand society through a sociological lens.

The chapters are grouped by themes: state and nation; ethnicity in Aotearoa New Zealand; social class and economic inequality; gender and sexuality; and contemporary issues. The last group of chapters includes ageing, domestic violence, imprisonment, the intersection between urban and rural dwellers, and climate change. Most chapters start with an historical background of the topic to provide context followed by a broad outline of the current situation in Aotearoa New Zealand in relation to the chapter topic. The historical back-drop is useful when reading each chapter; however, there is repetition between chapters. As each chapter has a limited word count, some chapters focus on some key areas rather than covering the topic in full. For example, in Richard Shaw's chapter about democracy he focuses on specifically on aspects of enfranchisement for Māori and women.

Unlike some edited books, where chapters have no obvious connections, the authors in this book have helpfully signposted links between chapters. Themes which run through the chapters also provide connections between chapters. Colonisation and institutional racism is one theme. This theme is raised in Chapter one, with an exploration of how the process of colonisation in Aotearoa New Zealand established a social and economic environment platform for capitalism to take hold, through to chapters in the last section where, for example, Tracey McIntosh and Bartek Goldman discuss institutional racism in the criminal justice system. Another theme running through the book is the impact on society of neoliberalism rolled out by the fourth Labour government in the 1980s. In a chapter about class divisions, Bruce Curtis and Marko Galic define neoliberalism as "a way of organising the capitalist economy that involves a focus on improving profitability" (p. 135). A number of authors also describe the hegemonic process, an aspect of neoliberalism whereby citizens are deceived into acting and voting against their own interests. This explains the insidious hold neoliberalism has over the Aotearoa New Zealand population.

Of interest to social workers working in the family violence sector is a chapter by Vivienne Elizabeth about intimate partner violence, marginalisation and masculinity. 
The wider context which creates the milieu in which intimate partner violence is likely to occur is outlined. The connection between neoliberalism and the construction of manhood based on being a successful breadwinner and feeling powerful through consumption is explained. The potential consequence for those who feel a failure when measured against this model of masculinity is the use of violence as a way to re-assert patriarchal power. Pressure men experience within society to be a certain way (also discussed in Richard Pringle's chapter on masculinity) is an area in which we as social workers can work to create change. This chapter provides clear links from the macro to the micro.
For social work students, this text will support learning about the way the personal is political within Aotearoa New Zealand society. It provides a context for understanding how social structures impact on everyday life. For social workers it is a useful resource to update our knowledge about the social, economic and political environment which affects the people we work with. However, due to the limited length of each chapter, for an in-depth grasp of each topic, wider reading is essential. Awareness of the impact of social structures on the personal is a foundation for social work and after 30 years of neoliberal politics this is more important than ever.

Reviewed by Lesley Pitt, Lecturer in Social Work, Open Polytechnic 